\title{
A Bibliometric Study of Postgraduate Theses in Library and Information Science: with special reference to University of Kelaniya and University of Colombo, Sri Lanka
}

\author{
Angammana, A.M.S. ${ }^{1}$ and Jayatissa, L.A. ${ }^{2}$
}

\begin{abstract}
Bibliometric analysis is used by an increasing number of researchers in the field of Library and Information Sciences (LIS). University libraries, which spend large amounts of fund annually to acquire information sources, face enormous problems related to the selection and the weeding out of publications. To minimize or overcome these problems, bibliometric studies are often used by librarians. The objective of the study is to ascertain bibliometric features visible in the field of Library and Information Sciences. For this purpose, 50 theses submitted for the Master of LIS degree (MLS) of the University of Colombo and 20 theses submitted for the Master of Social Science in LIS (MSSc) of the University of Kelaniya were analyzed. From those 70 theses, a total of 4,901 citations were extracted using the lists of references and bibliographies provided as the main source of primary data. These citations were cross classified and tabulated according to a number of variables. It was revealed that books were the most heavily used source material, accounting for $39 \%$ of citations, while journals category coming next with 34\% of citations. Most heavily used book was the "Organizational Behavior" by Robbins, (2001). "College and Research Libraries" is found to be the most heavily used journal. Within the span of 11 year study period, 485 journals were cited. A total of 1, 664 citations originated from these journals. The journal "College and Research Libraries" ranks as the first in the core journals list with 66 citations. "Library news" which ranks the second place accounts for 52 citations. The mean half-life of all citations is almost 9 years, while the mean half-life for journals and books are 7 years and 13 years, respectively. Findings of the study are in conformity with the previously reported research findings, which also reports that books as the main source material for research studies in LIS fields.
\end{abstract}

Keywords: Academic Libraries, Bibliometrics, Citations, Library and Information Sciences

\footnotetext{
${ }^{1}$ Senior Assistant Librarian, University of Sri Jayewardenepura. Email:santha@sjp.ac.lk

${ }^{2}$ Librarian, University of Kelaniya, Kelaniya.Email:jaya@kln.ac.lk
} 


\section{Introduction}

Bibliometrics is a type of research method used by the researchers in different subject disciplines. "Bibliometric techniques are used for a variety of purposes like the determination of various scientific indicators, the evaluation of scientific output, the selection of journals for libraries and even the forecasting of potential Nobel Laurates" (Zafrunnisha, 2012). The term Bibliometrics has been defined as, "the application of mathematics and statistical methods to books and other media of communication" (Prichered, 1969). Initially this concept originated as statistical bibliography and subsequently developed into a major field, now commonly known as bibliometric studies. It is used for evaluating text and information in this field. The bibliometrics is quantitative in nature and this technique can be effectively used in the field of Library and Information Science for the study of literature. It is observed that in the field of Library and Information Science this type of research is used more effectively to determine trends in literature. Bibliometric studies are useful particularly for the evaluation of library services, resource allocation, decision making, collection development, resource sharing and weeding. "Bibliometric analysis has become a well-established part of information research" (Zafrunnisha, 2012). Bibliometric study accurately used by the researchers to identify user requirement.

\section{Statement of the problem}

University libraries annually spend a large amount of funds in acquiring information sources required for its user community. It is necessary to conduct research studies to check the relevancy and the utilization of these information sources and to take action to obtain appropriate information sources to match the needs of the users.

In order to select information sources in various subject disciplines, the general rule of 80:20 can be used. According to this rule, eighty percent of the total usage is coming from $20 \%$ of the total collection. If librarians can identify this $20 \%$, most heavily used materials then the library can satisfy $80 \%$ of the user requirements. This rule is illustrated below in Figure 01. 
Academic libraries have limited space to store sources of information. Therefore it is necessary to formulate a mechanism to discard unwanted and under-utilized sources of information. The concept of half-life (determine when half of all the active literature of a field has been published) is used by researchers to discard library materials (Totten, 1971 p. 342). This concept is helpfully important to discard books and serial collections.

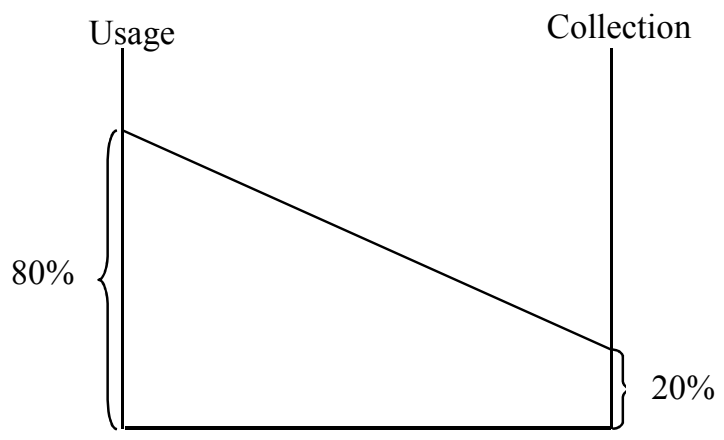

Figure 1: Selection of information sources

\section{Significance of the Study}

Bibliometric studies using postgraduate theses and dissertations in different disciplines have been done in various countries. Local literature however reveals that few such a studies have been carried out in Sri Lanka yet. Conducting a bibliometric study could be a valuable asset in many aspects for an academic library. This type of study using postgraduate theses is essential to determine the bibliometric features in a specific subject field. It helps to identify core journals "the journal publishing maximum number of papers in any area is considered a core journal" (Mattal \& Singh, 2006) and other heavily used information sources as well as source format and age of information sources. Such a procedure would help the librarians to manage their collection in an effective and an efficient manner.

It is essential to formulate collection development policies to determine whether to continue or discontinue a particular subscription. Such development policies would immensely help resource allocation, the weeding process regarding both print journals and books in a Library. The findings of 
this study will also help to avoid accepting unnecessary library materials from donors.

\section{Objectives of the Study}

The study was carried out to determine the bibliometric features of postgraduate theses in the field of Library and Information Science.

\section{Specific Objectives}

1. To determine bibliographic forms of generally used reference materials in the field of Library and Information Science.

2. To identify core journals used in postgraduate research studies in the field of Library and Information Sciences.

3. To identify heavily used books in the field of Library and Information Science

4. To find the half-life of reference sources in the field of Library and Information Science.

\section{Literature Review}

Many researchers in different subject areas have carried out bibliometric studies. These studies have covered many areas and have used different methodologies. A large number of bibliometric research studies in different disciplines are conducted in foreign countries. However, in Sri Lanka only a limited number bibliometric studies are recorded in the literature.

Gunasekera (2008) has conducted a research study on "Library and Information Science research literature in Sri Lanka: a Bibliometric study". The study examines 141 articles published during the period 1997 to 2007 to examine the characteristics of Library and Information Science literature in Sri Lanka. Ninety four percent of the articles were single authored. Author productivity did not fit the Lotka's Law and the average citation per article was nine.

Fasae (2011) worked on "citation analysis of M.Tech" a theses submitted to the department of Agricultural Economics and Extension, Federal University of Technology Akure, Nigeria. The focus of this study was to determine the 
materials used in masters theses in Agricultural Economics during the period 2005 to 2009. Journals were used extensively in their citations (32\%). One third of the cited materials (31\%) were 20 years or more. Most cited journal was Journal of Agricultural Economics with 51 citations.

Echezona et al. (2011) conducted a research study titled "Information Sources used by postgraduate students in Library and Information Science: a citation analysis of dissertations" at Nnamdi Azikiwe Library University of Nigeria, Nsukka. A total of 79 theses published during the period 1997 to 2007 were analyzed. References from Journal articles accounted for $53.8 \%$ of the citations while books accounted for 30.8\%. "College and Research Libraries" which was the most cited journal in this study.

Dickinson (2009) conducted a research study on "Reference Analysis as an Aid in Collection Development: a study of Master of Architecture Theses at Dalhousie University." This study has analyzed graduate architecture theses at the Dalhousie University in 2003 to 2006 to find out the age of materials and format. The result of this study revealed the age of materials as 18 years. The monograph reference was the highest reference source and it was $65 \%$.

Chikate and Patil (2008) conducted a research study on citation analysis of theses in Library and Information Science submitted to the University of Pune, India. Between 1982 and 2005, twenty seven LIS theses were selected as source of data and out of these twenty seven theses, more than 6000 citations were analyzed. Results showed that most widely used form of publication was journal articles with $42.2 \%$ citations. This study has tested Bradford's law of scattering and revealed that the citations fit well to the above Law.

Keat and Kaur (2008) conducted a research on "Citation study of Library and Information Science dissertations for collection development" The main objective of this study was to examine the use of information resources in preparing for dissertations in the field of Library and Information Science at the University of Malaya. For this research study 40 MLS theses were selected as the sample from the period 2000-2005. According to their research findings Journals and Books are the most used sources of information for Library and Information Science at the University of Malaya. 
Tonta and Al (2006) conducted a research study on scatter and obsolescence of journals cited in theses and dissertations in Librarianship using100 theses and dissertations that were submitted between 1974 and 2002 to the Department of Librarianship at Haccettepe University, Turkey. The main objective of that study was to identify bibliometric features of theses and dissertations. Research findings reveal that monographs were cited slightly more $(50 \%)$ than journals articles $(42 \%)$. Foreign journal titles fit to Bradford's Law of Scattering while the mean half-life for all references was 9 years.

Doraswamy and Reddy (2001) conducted a Citation analysis of $\mathrm{PhD}$ Geographical theses in Sri Venkateswara University, India during the period 1991-2000. This study analyzed 2471 citations and revealed that the most preferred source of information was books with $41.89 \%$. According to the rank list, the journal "Geographical Review of India" was placed first.

Sharma et al. (1999) conducted a research study titled "Bibliometric study of doctoral dissertations in Organic Chemistry submitted by $\mathrm{S} \& \mathrm{~T}$ workers of RRL, Jorhat to evaluate the utility factor of the library". Main objective of this study was to determine the usage pattern of the literature in the field of Organic Chemistry for which 4,277 citations were collected during 1977 to 1997 . The results showed that a majority of the citations were from journal articles. The half-life of literature in the field of Organic Chemistry was 27 years.

Vimala (1997) conducted a research study to find out citation pattern in Biological Sciences using theses submitted for doctoral degree awarded by Sri Venkateswara University, Tirupati, India. The author analyzed 39,453 citations and found that the most frequently used journal was "Plant Physiology" which got the first rank in the journal rank list. Twenty five percent of total citations use only the first nine journals in the rank list. Fifty (50) per cent of total citations were approximately 11 years old while books were approximately 13 years old. This research study revealed that the HalfLife period for book citation was little higher compared to journals 


\section{Research Methodology}

In order to gather background information, a literature survey was carried out. Bibliometric techniques are used as research methods. Bibliometric research methods are applied to determine the characteristics (user behavior) of the materials referenced by graduate students. For this study 50 MLS postgraduate theses submitted to the University of Colombo and 20 MSSc postgraduate theses submitted to University of Kelaniya within 11 year period from 1999 to 2009 have been considered as source documents. In order to make this research study a success all bibliographies and title pages of the selected 70 theses were examined and citations were recorded from the list of references of each of the thesis. From these seventy theses, a total of 4,901 citations were recorded. Bibliographies of theses have been used to collect data such as material titles, article title, year of source material, total number of citations, source type, and source format. Title pages provide information on the title of the thesis and the year of submission. All these data was then fed in to excel worksheet in order to tabulate and cross tabulate all information collected from these sources. Based on the MS Excel worksheet relevant Tables and Figures were extracted.

Using the above database the following bibliometric related analysis has been carried out. Initially, all reference materials were grouped in to 16 categories in order to identify the most heavily used reference materials in this field.

Annually, the budget allocation for the libraries has decreased. Therefore, the librarians have to cut down the purchasing of reference materials. This study identifies core journals and heavily used books in the field of Library and Information Science in order to facilitate the management of scarce resource available to a library.

There are a number of bibliometric laws available for the use of researchers, the most prominent laws are Lotka's inverse square law of scientific productivity, Zipf's Law about the frequency occurrence of words in a text and Bradford's law of scattering of articles. Out of these laws the present study has used the Bradford's law. The application of Bradford's law help in the collection evaluation, selection/deselection of materials, defining the core 
journals and to prepare priority lists among journals. In order to identify archival usage of reference materials, this study has tabulated the age distribution and also calculated half-life of all citations. The study has identified the difference of half-life by type of material. In order to present the results of this study, Tables, Figures and formulae and statistical techniques are used extensively.

\section{Bibliometric Analysis}

\section{Distribution of citations by type of source material}

Researchers in any subject field use various types of source materials. Literature reveals that bibliometric researchers have categorized all these source materials in to several groups according to their specific needs.

Source materials in this study are categorized into sixteen groups. Books, Journals, Theses \& dissertations, Conference papers, Dictionaries, Handbooks, Reports, Websites, Acts, Glossaries, Manuals, Pamphlets, Bibliographies, Newspapers, Newsletters, Others (Yearbooks, Abstract, Letters, Indexes, Gazettes).

Table 01 presents the distribution of various types of source materials used by researchers in the field of Library and Information Science. Out of a total of 4,901 citations, books were the heavily used source material accounting for $39.20 \%$. This was followed by journals, accounting for approximately $34 \%$. Web sites were the next most used source material in the field of Library and Information Science. However, web sites accounts for only $6.33 \%$. Nearly $80 \%$ of total citations were covered by the above three types of source materials. Remaining thirteen source materials have recorded less than $5 \%$ usage for each. The descending order of other materials cited are as follows; reports (4.35\%), Conference papers (3.92), theses \& dissertations (2.59\%), acts $(1.67 \%)$, newspapers $(1.61 \%)$, dictionaries $(1.29 \%)$, handbooks $(1.29 \%)$, other reference materials $(1.10 \%)$, newsletters $(0.94 \%)$, bibliographies $(0.82 \%)$, glossaries $(0.49 \%)$, manuals $(0.37 \%)$ and the lowest source material was Pamphlets which had recorded only $(0.10 \%)$ citations during the entire 11 years period. 
Table 01: Distribution of citations according to type of source material

\begin{tabular}{|l|r|r|r|}
\hline \multicolumn{1}{|c|}{ Data Source } & No. of citations & Percentage (\%) & $\begin{array}{c}\text { Cumulative } \\
\text { percentage }\end{array}$ \\
\hline Books & 1921 & 39.20 & 39.20 \\
\hline Journals & 1664 & 33.95 & 73.15 \\
\hline web sites & 310 & 6.33 & 79.48 \\
\hline Reports & 213 & 4.35 & 83.83 \\
\hline Conference papers & 192 & 3.92 & 87.75 \\
\hline Thesis & 127 & 2.59 & 90.34 \\
Dissertations & 82 & 1.67 & 92.01 \\
\hline Acts & 79 & 1.61 & 93.62 \\
\hline Newspapers & 63 & 1.29 & 94.91 \\
\hline Dictionaries & 63 & 1.29 & 96.20 \\
\hline Handbooks & 54 & 1.10 & 97.30 \\
\hline Others & 46 & 0.94 & 98.24 \\
\hline Newsletters & 40 & 0.82 & 99.06 \\
\hline Bibliographies & 24 & 0.49 & 99.55 \\
\hline Glossaries & 18 & 0.37 & 99.92 \\
\hline Manuals & 5 & 0.10 & 100.00 \\
\hline Pamphlets & $\mathbf{4 , 9 0 1}$ & $\mathbf{1 0 0}$ & \\
\hline Total & & & \\
\hline & 53 & & \\
\hline
\end{tabular}

\section{Rank list of journals}

This rank list of journals presented in table 6 below highlights the most frequently used journals by researchers in the field of Library and Information Science. Two types of rank lists have been created in order to identify core journals in the field of Library and Information Science.

- Total number of citations for a given journal

- Total number of theses with citations to a given journal

\section{Thirty core journals according to number of citations}

Thirty core journal (the most heavily referenced journals) in the field of Library and Information Science were identified using the number of citations. If 10 or more than 10 articles of a particular journal have been used by the researchers it is identified as a core journal in this study. The findings are presented in Table 02 below. 
Table 02 : Thirty core journals according to the number of citations

\begin{tabular}{|c|c|c|c|c|c|}
\hline No. & Rank & Journal Title & $\begin{array}{l}\text { No. of } \\
\text { citations }\end{array}$ & $\%$ & $\begin{array}{l}\text { Cumulative } \\
\text { percentage }\end{array}$ \\
\hline 1 & 1 & College and Research Libraries & 66 & 3.97 & 3.97 \\
\hline 2 & 2 & Library News & 52 & 3.13 & 7.10 \\
\hline 3 & 3 & Aslib proceedings & 50 & 3.01 & 10.11 \\
\hline 4 & 4 & Information Development & 49 & 2.95 & 13.06 \\
\hline 5 & 5 & Sri Lanka Library Review & 45 & 2.71 & 15.76 \\
\hline 6 & 6 & $\begin{array}{l}\text { Journal of Librarianship and } \\
\text { Information Science }\end{array}$ & 43 & 2.59 & 18.35 \\
\hline 7 & 7 & Library Management & 40 & 2.41 & 20.76 \\
\hline 8 & 8 & Journal of Documentation & 39 & 2.35 & 23.10 \\
\hline 9 & 9 & Library Trends & 38 & 2.29 & 25.39 \\
\hline 10 & 10 & Libri & 35 & 2.11 & 27.50 \\
\hline 11 & 11 & Library Quarterly & 33 & 1.99 & 29.48 \\
\hline 16 & 12 & Journal of Academic & 31 & 1.87 & 31.35 \\
\hline 12 & 13 & IFLA Journal & 30 & 1.81 & 33.15 \\
\hline 13 & 14 & Library Review & 26 & 1.56 & 34.72 \\
\hline 14 & 15 & $\begin{array}{l}\text { Performance Measurement and } \\
\text { Matrics }\end{array}$ & 24 & 1.44 & 36.16 \\
\hline 15 & 16 & Asian Libraries & 20 & 1.20 & 37.36 \\
\hline 17 & 17 & Journal of Librarianship & 18 & 1.08 & 38.45 \\
\hline 18 & 17 & Program & 18 & 1.08 & 39.53 \\
\hline 19 & 18 & Library Journal & 17 & 1.02 & 40.55 \\
\hline 20 & 19 & $\begin{array}{l}\text { Journal of the University } \\
\text { Librarian's Association of Sri }\end{array}$ & 16 & 0.96 & 41.52 \\
\hline 21 & 19 & $\begin{array}{l}\text { Journal of the American } \\
\text { Society for Information }\end{array}$ & 16 & 0.96 & 42.48 \\
\hline 22 & 20 & International Library Review & 15 & 0.90 & 43.38 \\
\hline 23 & 20 & Marketing Library Services & 15 & 0.90 & 44.28 \\
\hline 24 & 21 & $\begin{array}{l}\text { International Information and } \\
\text { Library Review }\end{array}$ & 14 & 0.84 & 45.13 \\
\hline 25 & 21 & $\begin{array}{l}\text { Journal of Library } \\
\text { Administration }\end{array}$ & 14 & 0.84 & 45.97 \\
\hline 26 & 22 & $\begin{array}{l}\text { International Library } \\
\text { Movement }\end{array}$ & 13 & 0.78 & 46.75 \\
\hline 27 & 22 & New Library World & 13 & 0.78 & 47.53 \\
\hline 28 & 23 & $\begin{array}{l}\text { Library Collections, } \\
\text { Acquisitions \& Technical } \\
\text { Services }\end{array}$ & 11 & 0.66 & 48.19 \\
\hline 29 & 23 & $\begin{array}{l}\text { Library Resource and } \\
\text { Technical Services }\end{array}$ & 11 & 0.66 & 48.86 \\
\hline 30 & 24 & Journal of Information Science & 10 & 0.60 & 49.46 \\
\hline
\end{tabular}


Any research study heavily depends on various types of information sources, such as Books, Journals, Pamphlets, Reports etc. Out of above sources of information, journal articles are the most commonly used source by the researchers. Therefore, it is necessary to identify core journals related to this field. Data collected for this study shows that 485 journals were used by the researchers and these journals contained 1,664 citations. Out of these 485 journals used by the researchers, most heavily cited 30 journals are presented in table number 02. Among them the journal "College and Research Library" has taken rank 1 with 66 citations. It accounts for $3.97 \%$ of total journal article citations. Rank number 2 goes to "Library News" with 52 citations accounting for $3.13 \%$ of total number of journal citations. "Aslib Proceedings" was the third highest with 50 citations and it accounts for 3.01\%. Thirteen journals have more than 25 numbers of citations and only seven has less than fifteen numbers of citations.

\section{Thirty core journals according to total number of theses}

Subsequently, the thirty core journals are tabulated according to total number of theses which enabled the researcher to find the highest number of users for a particular journal. Most of the bibliometric researchers select core journals using the highest number of citations without considering the number of users for each journal. To find core journals in any discipline, it is necessary to consider the number of users for each journal.

Table 03 shows the thirty core journals according to total number of theses. According to table 6 "Journal of Librarianship and Information Science" got the $6^{\text {th }}$ Rank, but the number of users for this journal was the highest that is 25 users (6.44\%). "College and Research Libraries" got the $6^{\text {th }}$ Rank with 19 users (4.90\%). "Aslib Proceedings" recorded the $2^{\text {nd }}$ highest number of users $(24$ users) with $6.19 \%$, while "Library News" is placed in rank 3. It is interesting to note that "Journal of the University Librarian's Association of Sri Lanka has got the $12^{\text {th }}$ Rank with 11 users. According to table number 02 which lists the 30 core journals, above journal is placed at number 19 .

According to Table 02 "Marketing Library Services" is placed in the $20^{\text {th }}$ rank with 15 citations $(0.90 \%)$ out of 30 core journals. However, table 03 shows that the above journal had been used by only one user. "International 
Information and Library Review" has 10 users but it had the $21^{\text {st }}$ rank in Table number 02 .

Table 03: Thirty core journals according to total number of theses

\begin{tabular}{|c|c|c|c|c|c|}
\hline No. & Rank & Journal title & $\begin{array}{l}\text { No. of } \\
\text { citations }\end{array}$ & $\begin{array}{l}\text { No. of } \\
\text { theses }\end{array}$ & $\%$ \\
\hline 1 & 1 & $\begin{array}{l}\text { Journal of Librarianship and } \\
\text { Information Science }\end{array}$ & 43 & 25 & 6.44 \\
\hline 2 & 2 & Aslib proceedings & 50 & 24 & 6.19 \\
\hline 3 & 3 & Library News & 52 & 23 & 5.93 \\
\hline 4 & 4 & Information Development & 49 & 22 & 5.67 \\
\hline 5 & 5 & Sri Lanka Library Review & 45 & 20 & 5.15 \\
\hline 6 & 6 & College and Research Libraries & 66 & 19 & 4.90 \\
\hline 7 & 6 & Libri & 35 & 19 & 4.90 \\
\hline 8 & 7 & Journal of Documentation & 39 & 18 & 4.64 \\
\hline 9 & 7 & Journal of Academic Librarianship & 31 & 18 & 4.64 \\
\hline 10 & 8 & Library Quarterly & 33 & 16 & 4.12 \\
\hline 11 & 8 & Library Review & 26 & 16 & 4.12 \\
\hline 12 & 9 & Library Trends & 38 & 15 & 3.87 \\
\hline 13 & 10 & Library Management & 40 & 13 & 3.35 \\
\hline 14 & 10 & Asian Libraries & 20 & 13 & 3.35 \\
\hline 15 & 11 & IFLA Journal & 30 & 12 & 3.09 \\
\hline 16 & 11 & Journal of Librarianship & 18 & 12 & 3.09 \\
\hline 17 & 12 & $\begin{array}{l}\text { Journal of the University Librarian's } \\
\text { Association of Sri Lanka }\end{array}$ & 16 & 11 & 2.84 \\
\hline 18 & 13 & International Library Review & 15 & 10 & 2.58 \\
\hline 19 & 13 & $\begin{array}{l}\text { International Information and } \\
\text { Library Review }\end{array}$ & 14 & 10 & 2.58 \\
\hline 20 & 14 & Program & 18 & 9 & 2.32 \\
\hline 21 & 14 & $\begin{array}{l}\text { Journal of the American Society for } \\
\text { Information Science }\end{array}$ & 16 & 9 & 2.32 \\
\hline 22 & 14 & $\begin{array}{l}\text { Library Resource and Technical } \\
\text { Services }\end{array}$ & 11 & 9 & 2.32 \\
\hline 23 & 15 & Journal of Library Administration & 14 & 8 & 2.06 \\
\hline 24 & 15 & New Library World & 13 & 8 & 2.06 \\
\hline 25 & 15 & Journal of Information Science & 10 & 8 & 2.06 \\
\hline 26 & 16 & Library Journal & 17 & 7 & 1.80 \\
\hline 27 & 17 & International Library Movement & 13 & 6 & 1.55 \\
\hline 28 & 18 & $\begin{array}{l}\text { Performance Measurement and } \\
\text { Matrics }\end{array}$ & 24 & 4 & 1.03 \\
\hline 29 & 19 & $\begin{array}{l}\text { Library Collections, Acquisitions \& } \\
\text { Technical Services }\end{array}$ & 11 & 3 & 0.77 \\
\hline 30 & 20 & Marketing Library Services & 15 & 1 & 0.26 \\
\hline Total & & & 822 & 388 & 100.00 \\
\hline
\end{tabular}


According to the above mentioned core journal definition "Journal of Librarianship and Information Science" should get the first rank in the core journal reference list. "Aslib proceedings" and "Library News" should get second and third ranks respectively.

\section{The most heavily used books}

It is essential to identify heavily used books in any subject discipline. This study has identified highly used books in postgraduate theses in the field of Library and Information Science during the period 1999-2009.

Table 04: Most heavily used books

\begin{tabular}{|l|l|l|c|}
\hline $\begin{array}{c}\text { Ref. } \\
\text { No. }\end{array}$ & \multicolumn{1}{|c|}{ Title } & \multicolumn{1}{|c|}{ Author(s)/ editor(s) } & $\begin{array}{c}\text { No. of } \\
\text { citations }\end{array}$ \\
\hline 1 & Organizational Behaviour & Robbins, Stephen P. & 16 \\
\hline 2 & $\begin{array}{l}\text { Encyclopedia of Information and } \\
\text { Library Science }\end{array}$ & $\begin{array}{l}\text { Ishvari Corea, Gad } \\
\text { David Ojuando and } \\
\text { Khalid Kamal Faruqi }\end{array}$ & 15 \\
\hline 3 & $\begin{array}{l}\text { Cost analysis cost recovery marketing } \\
\text { and fee-based services }\end{array}$ & M. Sandra Wood & 15 \\
\hline 4 & Human Resource Management & Armstrong, M. & 14 \\
\hline 5 & Tripitakaya (Sinhala text) & & 13 \\
\hline 6 & Academic library Management & Line, M.B. & 13 \\
\hline 7 & $\begin{array}{l}\text { Encyclopedia of library and Information } \\
\text { Science }\end{array}$ & $\begin{array}{l}\text { Kent, Allen..[et al] } \\
\text { Research Methods in Librarianship : }\end{array}$ & $\begin{array}{l}\text { Busha, C.H. and } \\
\text { Harfer, S.P. }\end{array}$ \\
\hline 8 & Management & $\begin{array}{l}\text { Robbins, S.P. and } \\
\text { Coulter, M }\end{array}$ & 11 \\
\hline 9 & Nair, R. Raman & 11 \\
\hline 10 & Academic library automation & Nanterpretation & 11 \\
\hline
\end{tabular}

Table 04 shows the usage of books in the field of Library and Information Science within the period of analysis. In the present study, if books have more than eleven citations, they are considered as most heavily used. 'Organizational Behavior' by S.P. Robbins (2001) is the most used book with 16 references. There were ten books which have more than 10 citations. The 70 theses from which the data was extracted for this study, accounted for a total of 1,921 book citations. Out of these citations, 131 came from the list of most heavily used books. 


\section{Distribution of citations to journals according to Bradford's law}

Table 05: Bradford's Law of scattering

\begin{tabular}{|l|r|r|r|r|}
\hline Zone & $\begin{array}{c}\text { Number } \\
\text { of } \\
\text { Journals }\end{array}$ & $\begin{array}{c}\text { Number of } \\
\text { Citations }\end{array}$ & Ratio & \multicolumn{2}{|c|}{$\begin{array}{c}\text { According to } \\
\text { Bradford's } \\
\text { Law }\end{array}$} \\
\hline 1 & 13 & 551 & 1 & 1 \\
\hline 2 & 61 & 552 & 5 & 5 \\
\hline 3 & 411 & 561 & 32 & 25 \\
\hline Total & $\mathbf{4 8 5}$ & $\mathbf{1 , 6 6 4}$ & & \\
\hline
\end{tabular}

Based on the total number of journals and citations, Bradford's Law of scattering is tested. According to the above mentioned Bradford's Law one third of all journal citations are covered by a fewer number of journals while the second one third of the citations are covered by a greater number of journals than the first one third. Remaining one third of the citations is covered by still a greater number of journals than the second one third. Table 05 shows that 485 journal titles were used by researchers in the field of Library and Information Science and all these journal titles contained 1,664 citations. First one third of journal citations were 551 and it was covered by 13 journals. Second one third of journal citations were 552 and it was covered by 61 journals. The third one third of citations was covered by 411 journals. Bradford formulated his Law 1:n:n2 in order to identify scattering pattern of journal articles. According to our research findings, the journal citations which were collected for this study approximately fit the Bradford's Law of scattering. Accordingly, if librarians are able to subscribe to the above mentioned 13 journal titles that alone would help fulfill $1 / 3$ of the information requirements of the researchers in the field of Library and Information Science.

\section{Age of cited materials}

Researchers use various types of information sources as citations for their studies. Therefore, it is mandatory, that professionals in the field of Library Science know the age of all information sources. The present study analyzed the published year of each reference source in order to find out whether the researchers are using recent publications or the old ones. Furthermore, the year of publication is very important for librarians to manage their collection in an 
efficient and an effective manner. Age is the length of time a particular reference material has existed. These reference ages are usually measured in years. The half-life of all citations is derived from data collected for this study. Half-life of all of reference materials were calculated using the following formula.

$\mathrm{A}=\mathrm{SY}-\mathrm{PY}$

$A=$ age of reference material, SY=Submission year of thesis, $P Y=$ published year of reference material

Table 05 shows the age distribution of reference materials with corresponding overall frequency and cumulative percentage of citations. This data is used to determine the ages of reference materials used by the Library and Information Science postgraduate researchers. Fifty two references materials were published in the same year as the submission of theses. More than one quarter of citations were 05 or less years of age. More than half of the citations were almost 10 years old and more than 75 percent of citations were 19 years old. It is evident that the most number of citations (306) were 05 years old. It is interesting to note that 16 citations that were used are more than 100 years old. 132 citations have not indicated the publication year and were excluded from this calculation. $50 \%$ of the total number of 4,769 citations is nearly recorded in 9 year with 2,341 citations.

Figure 02 presents the cumulative percentage of all citations used by the researchers. $\mathrm{Y}$ axis of the above figure indicates the cumulative percentage of the citations and $X$ axis indicates the number of years. To find out the half-life of these references, a line is drawn from $\mathrm{Y}$ axis (point $\mathrm{A}$ ) to meet the curve (point $\mathrm{B}$ ) and the line drawn from point $\mathrm{B}$ to $\mathrm{C}$ meet the $\mathrm{X}$ axis at point $\mathrm{C}$, which is year 09 . 
Table 06: Age distribution and half-life of all citations

\begin{tabular}{|c|c|c|c|}
\hline $\begin{array}{c}\text { Age }(\mathbf{A}) \\
\text { years }\end{array}$ & $\begin{array}{c}\text { No. of } \\
\text { Ref. (R) }\end{array}$ & 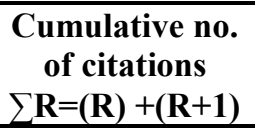 & $\begin{array}{c}\text { Cumulative } \\
\text { Percentage } \\
\left(\mathbf{R} / \sum \mathbf{R}\right) \\
\end{array}$ \\
\hline $\begin{array}{l}\text { Same } \\
\text { year }\end{array}$ & 52 & 52 & 1.09 \\
\hline 1 & 156 & 208 & 4.36 \\
\hline 2 & 218 & 426 & 8.93 \\
\hline 3 & 300 & 726 & 15.22 \\
\hline 4 & 296 & 1022 & 21.43 \\
\hline 5 & 306 & 1328 & 27.85 \\
\hline 6 & 295 & 1623 & 34.03 \\
\hline 7 & 266 & 1889 & 39.61 \\
\hline 8 & 233 & 2122 & 44.5 \\
\hline 9 & 219 & 2341 & 49.09 \\
\hline 10 & 208 & 2549 & 53.45 \\
\hline 11 & 203 & 2752 & 57.71 \\
\hline 12 & 167 & 2919 & 61.21 \\
\hline 13 & 119 & 3038 & 63.7 \\
\hline 14 & 111 & 3149 & 66.03 \\
\hline 15 & 111 & 3260 & 68.36 \\
\hline 16 & 100 & 3360 & 70.46 \\
\hline 17 & 71 & 3431 & 71.94 \\
\hline 18 & 83 & 3514 & 73.68 \\
\hline 19 & 70 & 3584 & 75.15 \\
\hline $20-30$ & 640 & 4224 & 88.57 \\
\hline $31-40$ & 292 & 4516 & 94.69 \\
\hline $41-50$ & 118 & 4634 & 97.17 \\
\hline $51-75$ & 88 & 4722 & 99.01 \\
\hline $76-100$ & 31 & 4753 & 99.66 \\
\hline $\begin{array}{l}\text { More } \\
\text { than } 100\end{array}$ & 16 & 4769 & 100 \\
\hline
\end{tabular}




\section{Cumulative percentage of all citations}

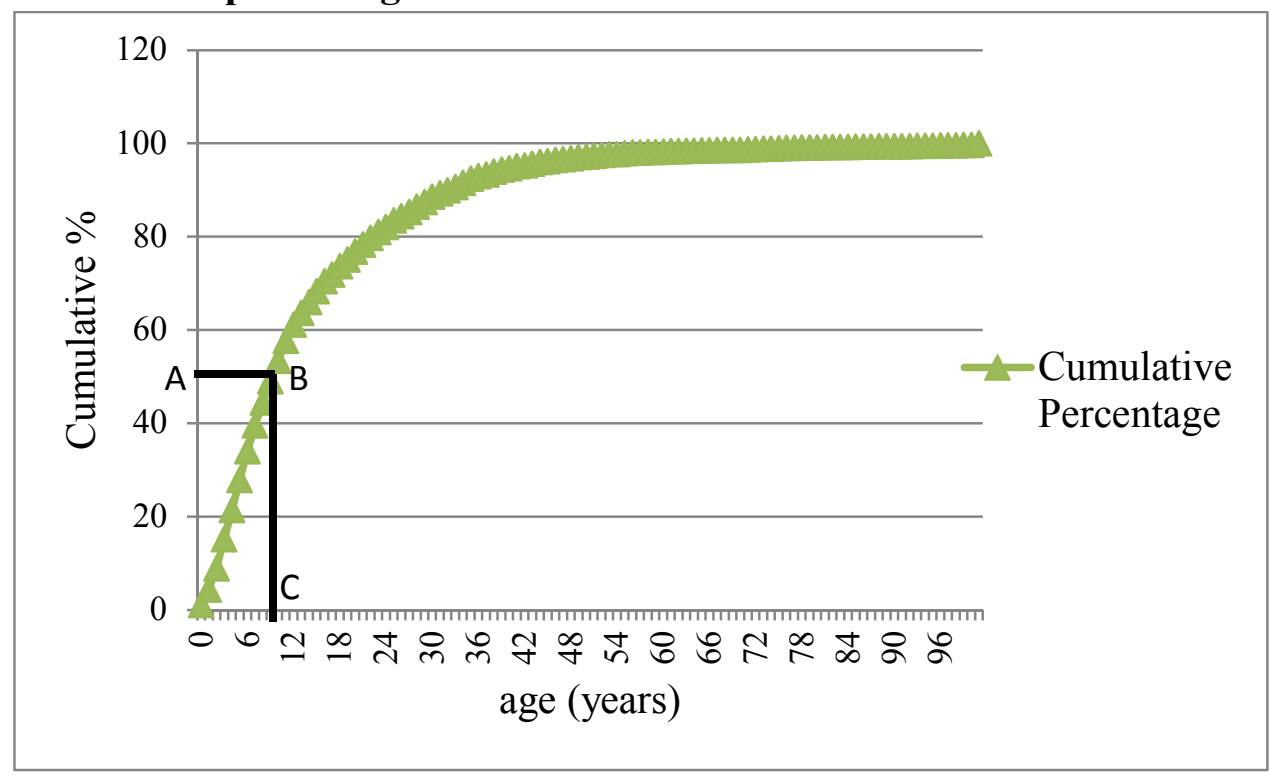

Figure 02: Cumulative percentage of all citations

\section{Discussion}

This bibliometric study is based on the Master of Library and Information Science (MLS) theses submitted to the Faculty of Graduate studies, University of Colombo and Master of Social Science in Library and Information Science (MSSc) theses submitted to the University of Kelaniya in the field of Library and Information Science within 11 year period from1999 to 2009. Within the selected study period fifty theses were submitted to the University of Colombo and twenty theses to the University of Kelaniya. From these seventy theses a total of 4,901 citations were initially recorded.

Research findings point to the fact that books and journals are the most used reference materials surpassing all other types of source materials. Out of all types of citations, books accounts for approximately 39\% while journal citation account for approximately $34 \%$. Each of the other source materials records less than seven percent usage. We may therefore conclude that the most preferred source material is books closely followed by journals. 
Present study analyzed journal article citations to find out core journals in the field of Library and Information Science. Within the 11 year study period 485 journals were cited. A total of 1, 664 citations originated from these journals. The journal "College and Research Libraries" with rank one in the core journal list accounts for 66 references. "Library news" with rank 2 accounts for 52 citations, "Aslib proceedings" has 50 citations with rank 3. This study considered not only the number of citations but also the number of users for a particular core journal. "Journal of Librarianship and Information Science "recorded the highest number of users that is 25 out of 70. Second highest number of users was recorded for the journal "Aslib proceedings "with 24 users and "Library News" was the third with 23 users.

Books were the main reference material used by researchers in the field of Library and Information Science. The present researcher was therefore; keen to identify the most heavily used books in this field. Among them "Organizational Behavior" by S.P.Robbins is the most used book with 16 citations. The second highest usage of book citations are "Encyclopedia of Information and Library Science" and "Cost analysis cost recovery marketing and free-base services" with 15 references each. It is interesting to note that the most heavily used book in the field of Library and Information Science come from a non-library science discipline.

Several bibliometric laws are used by the researchers for studying of bibliometric features. In order to identify the heavily used journal titles in the field of Library and Information Science the present study used Bradford's law of scattering. MLS and MSSc researchers have used 485 journal titles with 1664 citations. The findings nearly endorse the Bradford's law of scattering and the research indicates that one third of journal needs were met by a 13 journal titles only.

Age of reference materials is very important for librarians when preparing withdrawal policies. In order to facilitate these procedures present study has calculated half-life of all citations. The study reveals that approximately 50\% of all citations were 9 years old. When considering the half-life of journals and books separately, books have half-life period of 13 years, while journals' halflife period is only 7 years. Rather than use old articles researchers in the field 
of Library and Information Science seem to prefer the use of current journal articles. According to the research findings, $80 \%$ of the total journal article needs in the field of Library and Information Science can be met by keeping just the 16 year old journals. A research study by Vimala (1997) revealed that half-life of journal citation is 11 years in the field of in Biological Sciences. Reddy (1999) discovered that, the half-life of journal citations is 18 years in the field of Chemistry. Harwade and Dankhade (2002) revealed that the halflife of journal reference is 22 years in the field of Economics. According to the above findings half-life of journal references varies from subject discipline to subject discipline. Present study records the lowest journal half-life which is 7 years compared to above findings on half-life. We may therefore conclude that Library and Information Science researchers prefer to use more current information in their research studies.

According to Bradford's law, researcher has identified 13 core journals. These journals cover one third of journals article needs in the field of Library and Information Science.

\section{Conclusions}

Books were the most heavily used source material in the field of Library and Information Science which is closely followed by journals.

Journals seem to be an important reference material in the field of Library and Information Science. The researcher therefore has identified core journals related to this field. The journal 'College and Research Libraries' was the most cited journal in the field of Library and Information Science. However the 'Journal of Librarianship and Information Science' records a higher number of users than the Journal of "College and Research Libraries". Distribution of core journal references by place of publication shows that more journals are published internationally whereas the local publications are very few.

Highest number of citations came from books. The present research has identified the highly used books within the field. The book titled "Organizational Behavior" was the most heavily used book in the field of Library and Information Science. Overall half-life value for all citation is nine 
years. When half-life of books and journals citations are considered separately books have longer half-life period (13 years) compared to half-life of journal citations ( 7 years).

\section{Recommendations}

Books were most widely used source material in the field of Library and Information Science. According to the findings of the present bibliometric study, researchers have not used enough current scholarly articles as reference material. Therefore, to strengthen the quality of postgraduate research, researchers should be encouraged to use more current articles. To achieve this mission training programme in literature searching should be made a compulsory part of course modules in master's degree programmes.

It is recommended that it is better if these university libraries could subscribe to at least 13 most used journals. According to the Bradfords' Law, these 13 journals can fulfill one third of all requirement of the researchers. According to the 20:80 rules, librarians can withdraw unnecessary back volumes of print journals and books, which will avoid shelving and space problems (Lininger, 2012).

Based on the results of this research study, we may recommend that librarians conduct further bibliometric research studies in other disciplines as well. Librarians can benefit from such research findings. Such information can be used for decision making, and for the preparation of overall policies for university libraries. Continuation or discontinuation of particular subscriptions can be based on specific recommendations given by the researchers.

If librarians are unable to subscribe to 30 journals which are identified within this study as core journals, it is recommended that they should subscribe to at least 13 journals in order to cover one third of total journal references needed. 


\section{References}

Chikate, R. V., \& Patil, S. K. (2008). Citation analysis of theses in library and information science submitted to university of pune: A pilot study. Library Philosophy and Practice, 1-15. Retrieved from http://digitalcommons.unl.

edu/cgi/viewcontent.cgi?article $=1224 \&$ context $=$ libphilprac. Accessed on 12 February, 2015

Dickinson, K., Bryanna, B., \& Regan, G. (2009). Reference analysis as an aid in collection development: a study of master of architecture theses at dalhousie university. Dalhousie Journal of Interdisciplinary Management, 14(4), 1-11. Retrieved from http://djim.management.dal.ca/issue_pdfs/Vol4/Kelly_Reference Analysis as.pdf Accessed on 25 February, 2015

Doraswamy\& Reddy, P. (2001).Citation analysis of Ph.D theses in Geography. University News. 39, 3-7.

Echezona, R. I., Okafor, V. N., \&Ukwoma, S. C. (2011). Information sources used by postgraduate students in library and information science: a citation analysis of dissertations. Library Philosophy and Practice, 7(1), Retrieved from http://unllib. unl.edu/LPP/. Accessed on 4 February, 2015

Fasae, J. K. (2011). Citation analysis of m.tech theses submitted in the department of agricultural economics and extension, federal university of technology akure, nigeria. Collection Building, 30(4), 179-183. Retrieved from http://dx.doi.org. Accessed on 15 February, 2015

Gunasekera, C. (2008). Library and information science research literature in Sri Lanka : a bibliometric study. Journal of the University Librarians Association of Sri Lanka, 12, 17-48.

Keat, Y. C., \&Kaur, K. (2008).Citation study of library and information science dissertations for collection development.Malaysian Journal of Library \& Information Science, 13(2), 29-47.Retrieved from http://umepublication.um. edu.my/ filebank/published article/2317/658.pdf Accessed on 10 March, 2015

Lininger, A. (2012). 80/20 Collection Development. Public libraries online. Retrieved from http://publiclibrariesonline.org/2012/11/8020collection-development/ Accessed on 26 February, 2015

Mittal, R., Sharma, A., \& Singh, G. (2006). Periodical literature on library and information science education : a bibliometric study. Annals of Library and Information Studies, 53(4), 224-229. Retrieved from http://nopr.niscair.res.in/bitstream/123456789/6030/1/ALIS\%2053(4) \%20224-229.pdf. Accessed on 10 March, 2015 
Prichered, A. (1969). Statistical bibliography or bibliometrics.Journal of Documentation, 25(4), 348-349.

Tonta, Y., \& AL, U. (2006). Scatter and obsolescence of journals cited in theses and dissertations of librarianship. Library and information Science Research, 28, 281-296. Retrieved from http://eprints.rclis.org/9441/ Accessed on 11 March, 2015

Totten, H.L. (1971). The Selection of Library Materials for Storage: A State of the Art Retrieved from https://www.ideals.illinois.edu/ bitstream/handle/2142/6567/librarytrendsv19i3h_opt.pdf?sequence $=1$ Accessed on February 26, 2015.

Vimala, V. (1997) (as cited in N.Zafrunnisha,2012) Citation pattern in $\mathrm{PhD}$ theses in Biological Sciences submitted for the award of doctoral degree to S.V. University.

Zafrunnisha, N. (2012) Citation Analysis of PhD Theses in Psychology of Selected Universities in Andhra Pradesh, India, Library Philosophy and Practice, 11-19. Retrieved from http://unllib.unl.edu/LPP/nisha.pdf. Accessed on 10 March, 2015 